\title{
Regenerative Organic Agriculture: Charging the Soil Carbon Battery
}

\author{
Paul Reed Hepperly* \\ University of Illinois at Urbana-Champaign, USA
}

Submission: February 05, 2017; Published: August 25, 2017

*Corresponding author: Paul Reed Hepperly, University of Illinois at Urbana-Champaign, USA, Email: paul.hepperly@gmail.com

\section{Opinion}

Robert Rodale shown above is seen slightly before his death. Rodale was the prime advocate of organic agriculture a type of agriculture that does not use restricted synthetic chemical inputs. He coined the concept of regenerative organic agriculture in 1980's. Rodale's term regenerative organic agriculture was not an easy sell particularly in the beginning because it was not clearly demonstrated for people to see especially the scientific community who were keen about the ability of inputs to solve their problems and issues. Lately thanks to many years of diligent work it is becoming used more and more demonstrated. Much of this change can be attributed to the scientific trials funded by the Rodale family and Institute.

In 1973 the Rodale family purchased a wore down farm in Kutztown Pennsylvania and began to transform the farming away from a continuous maize or corn monoculture completely dependent on synthetic chemical inputs into a diversified farming without the use of synthetic chemical fertilizers or pesticides, organic. Rodale was an avid sportsman and enjoyed envisioning his beloved soil like an athlete. An athlete feed and trained can be built up for powerful performance and also when poorly trained and fed he/she would run down. The ability of agricultural system to lead to degraded soil resources and abandoned civilizations is well documented. George Washington Carver, the genius born slave the black wizard of Tuskegee, saw likewise that the degradation of southeastern soils as a consequence of cotton monocultures and his solution was introduction of crops like peanut and sweet potatoes. Using the right crops and practices the monoculture led degradation of land can be reversed and this can greatly benefit mankind now and in the future. This reversal of agricultural practice and policy was coined regeneration.
Regeneration can be likened to its ancient origins signifying to put back life (re) or energy/life (generon). The Rodale work The Rodale Farming System Trial addressed the regenerative organic concept using farming system trials which were well replicated and randomized and used normal farming equipment based on large plot sizes. The check treatment was conventional agriculture with the recommended synthetic chemical treatments in a maize and soybean typical rotation which predominates North American conventional agriculture. Organic systems used diversified crop rotation wheat; soybean maize rotation that featured cover crops and manure compost both organic systems received no synthetic chemical amendments (Figure 1). After 3 years of this historic trial the yields of the synthetic input treatment and the organic systems were not different statistically in yield and quality in normal rainfall years (Figure 2).

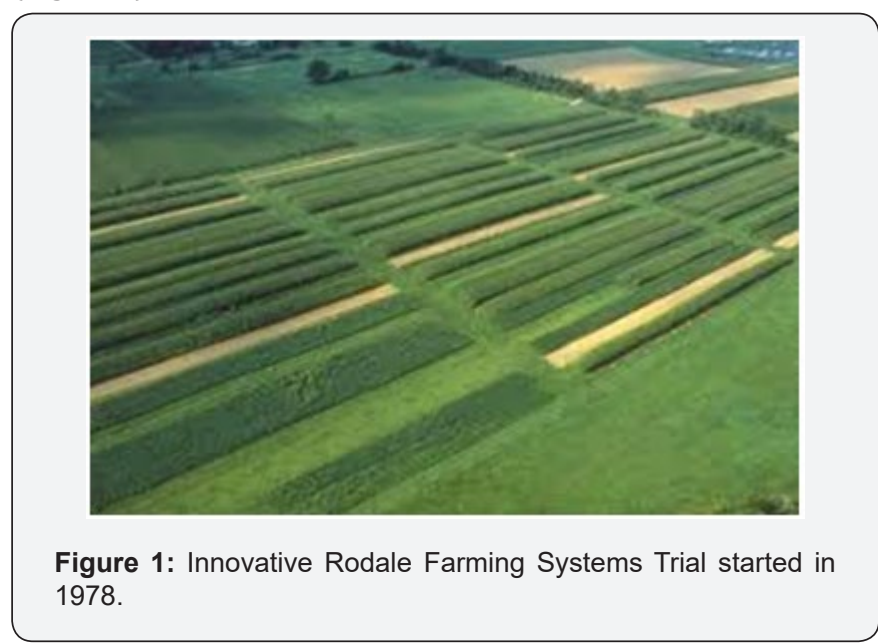




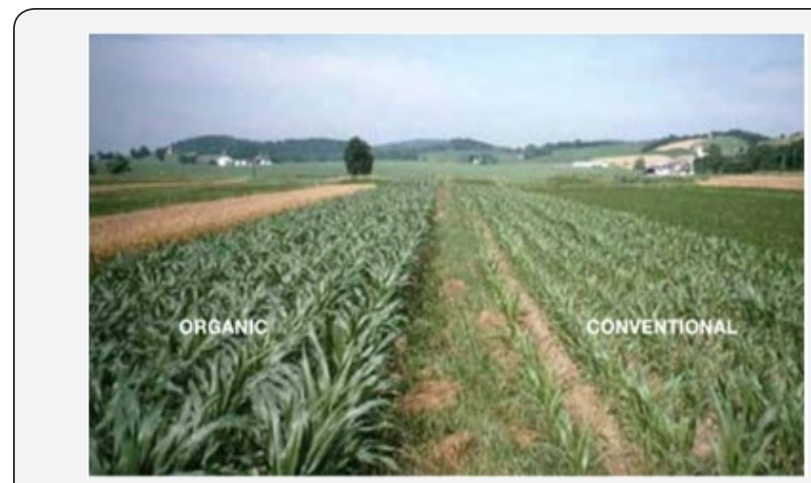

Figure 2: Corn in the legume based (left) and conventional (right) plots six week after planting during the 1995 drought. The conventional corn is showing signs of water stress.

Source: Rodale institute.

After this 3 year transition the yield of organic systems were superior to the conventional input in drought yields 25 and $50 \%$ for the maize and soybean crops, respectively. Over the trial more than 30 years the carbon and nitrogen in the soil has increased in the regenerative organic systems by about $1 \%$ and $0.5 \%$ from the original baseline amounts in carbon and nitrogen, respectively, while there has been no detection of any increase in the conventional agricultural system (Figure 3).

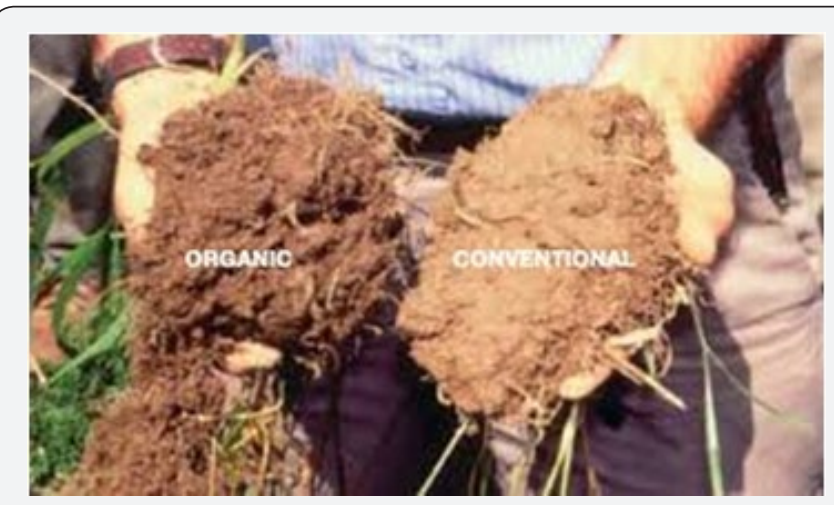

Figure 3: Regeneration of the soil structure of the organic farming systems can be shown compared to the same field with a conventional farming system legacy.

Regeneration of the soil structure of the organic farming systems can be shown compared to the same field with a conventional farming system legacy. Since the Farming System Trial has been a living laboratory for dozens of scientists and students measurement of soil life forms has shown returned numbers, activities and benefits from diverse soil life forms including bacteria, fungi, earthworms, ground insects and plant roots. The below figure demonstrates the sustained depleted state of the conventional farming system soil which the two regenerative organic systems both increase soil carbon another term for organic matter in a continuing progressive manner (Figure 4).

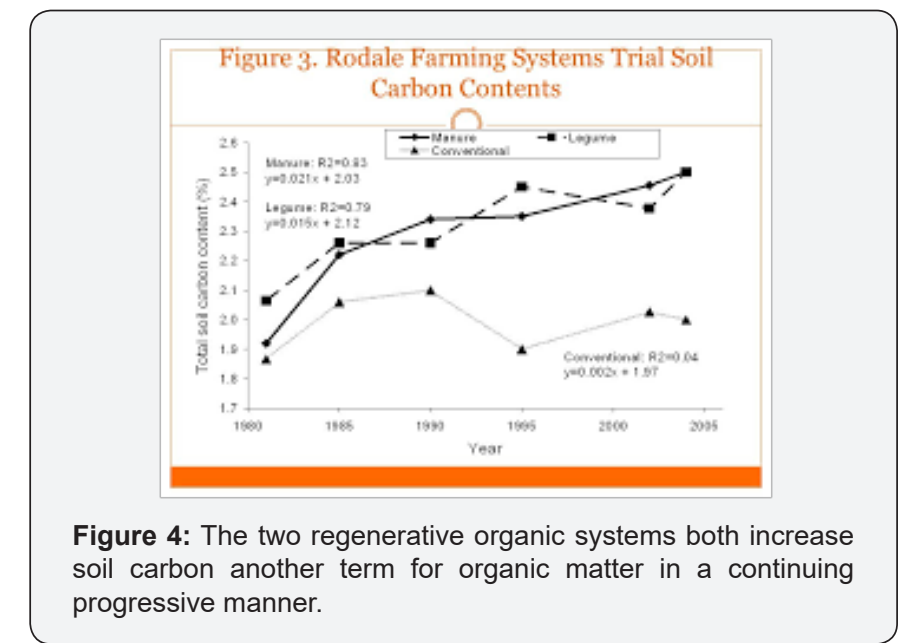

The proven dramatic results of the Rodale Farming Systems Trial are related to the ability to regenerate soil organic matter supplies through Regenerative Organic Agriculture practices envisioned by Robert Rodale. We envision the living farming system functioning like a carbon charged battery. Under the regenerated organic farming systems soils are charged with carbon and nitrogen. They are improved an array of increased life measurements in the soil and outside it. For example, because the synthetic chemicals are withdrawn, the economics and energetic of the systems improve for farmers and society. The reduction of inputs reduces the farming system carbon footprint in the emissions to produce those additions but even more import the positive carbon footprint from cover crops, better rotations, reducing tillage, and organic amendment charges the soil carbon battery.

This strategy of regenerative organic agriculture is more important now than ever since it seems to be the best tool for reducing excess greenhouse gases in the atmosphere by repatriating them in our soil to improve our food system and the environment and better feeding a growing global population. 
This work is licensed under Creative Commons Attribution 4.0 License

DOI: 10.19080/ARTOAJ.2017.10.555793
Your next submission with Juniper Publishers will reach you the below assets

- Quality Editorial service

- Swift Peer Review

- Reprints availability

- E-prints Service

- Manuscript Podcast for convenient understanding

- Global attainment for your research

- Manuscript accessibility in different formats

( Pdf, E-pub, Full Text, Audio)

- Unceasing customer service

Track the below URL for one-step submission https://juniperpublishers.com/online-submission.php 